\title{
B-1 cell: the precursor of a novel mononuclear phagocyte with immuno-regulatory properties
}

\author{
JOSÉ DANIEL LOPES and MARIO MARIANO \\ Departamento de Microbiologia, Imunologia e Parasitologia, Universidade Federal de São Paulo
}

Rua Botucatu, 862, $4^{\circ}$ andar, 04023-900 São Paulo, SP, Brasil

Manuscript received on July 14, 2008; accepted for publication on February 21, 2009;

presented by LUIZ R. TRAVASSOS

\begin{abstract}
Characterization of the origin, properties, functions and fate of cells is a fundamental task for the understanding of physiological and pathological phenomena. Despite the bulk of knowledge concerning the diverse characteristics of mammalian cells, some of them, such as B-1 cells, are still poorly understood. Here we report the results obtained in our laboratory on these cells in the last 10 years. After showing that B-1 cells could be cultured and amplified in vitro, a series of experiments were performed with these cells. They showed that B1 cells reside mostly in the peritoneal and pleural cavities, migrate to distant inflammatory foci, coalesce to form giant cells and participate in granuloma formation, both in vitro and in vivo. They are also able to present antigens to immunologically responsive cells and are endowed with regulatory properties. Further, we have also shown that these cells facilitate different types of infection as well as tumor growth and spreading. These data are presently reviewed pointing to a pivotal role that these cells may play in innate and acquired immunity.
\end{abstract}

Key words: B-1 cells, IL-10, inflammation, infection, neoplasia, BALB/Xid mice.

\section{INTRODUCTION}

B-1 cells, first characterized by Hayakawa et al. in 1985, express the phenotype $\operatorname{IgD}^{\text {low }} \operatorname{IgM}^{\text {hi }} \mathrm{CD} 23-\mathrm{CD} 19^{+} \mathrm{CD} 11 \mathrm{~b}^{+}$ whilst conventional $\mathrm{B}$ cells are identified by the phenotype $\mathrm{IgD}^{\text {hi }} \mathrm{IgM}^{\text {low }} \mathrm{CD} 23^{+} \mathrm{CD} 19^{+} \mathrm{CD} 11 \mathrm{~b}^{-} \mathrm{CD}^{-}$. Further, B1a cells differ from $\mathrm{B}-1 \mathrm{~b}$ cells by the expression of $\mathrm{CD} 5$ molecules in the former.

In addition to the promiscuous expression of markers for lymphoid and myeloid cell lineages, added with the CD5 T cell marker, these cells have also a peculiar distribution in the body's economy of mice: they are predominantly found in pleural and peritoneal cavities, being few in the spleen and almost absent in lymph nodes (Forster et al. 1991, Marcos et al. 1989, Hayakawa et

In commemoration of the $75^{\text {th }}$ anniversary of

Escola Paulista de Medicina/Universidade Federal de São Paulo.

Correspondence to: Dr. José Daniel Lopes

E-mail: jdlopes@unifesp.br al. 1985). Contrary to the bone marrow origin of conventional B cells, B-1 are long-lived and auto-renewing cells (Lalor et al. 1989).

The origin of B-1 cells is still a matter of intense investigation and two current hypotheses try to elucidate this issue. One, addressed by Herzenberg and Kantor (1993) says that B-1 cells do not differentiate from bone marrow precursors, but from cells which rearrange their Ig genes during fetal and neonatal period of life. Based on this hypothesis, the authors proposed that different lineages of B lymphocytes, B-1 and conventional B lymphocytes, are descendents of distinct precursors, each being active in different phases of the immune system development. This proposal was supported by experiments of cell reconstitution in SCID mice. It was demonstrated that cells from the fetal liver can reconstitute B1 and B-2 cells (Herzenberg and Kantor 1993, Hardy 
and Hayakawa 1995), whereas cells from the paraortic splancnopleura of 9 days embryo reconstitute the B-1a population (Godin et al. 1993). Finally, grafts of fetal omentum reconstitute the populations of B-1a and B-1b cells (Solvason et al. 1991). Based on these data, the authors concluded that B-1 cells appear in ontogeny before the emergence of conventional B cells, thus supporting the two cell lineage origin of B cells.

Conversely, Haughton and collaborators (1993) proposed that all sub-types of B cells emerge from a common progenitor, and that commitment with a cell lineage is dependent on the influence of antigenic selection (Cong et al. 1991). The authors reported that conventional B cells, cultured in the presence of antiIgM and IL-6, assume the B-1 phenotype. Based on these observations, the authors concluded that the commitment with B-1 phenotype occurs after IgM expression on the cell surface of not fully differentiated B cells. Sustaining this hypothesis, the authors showed that B cells stimulated with thymus-independent antigens, such as carbohydrate from bacteria, or by auto-antigens such as DNA, can differentiate into B-1 cells.

\section{B-1 CELLS HAVE A PECULIAR MORPHOLOGY}

Until recently, the morphology of B-1 cells was not fully characterized. Abrahão et al. (2003), in our laboratory, identified B-1 cells using colloidal gold immunocytochemical assays and purified B-1 cells from supernatants of adherent peritoneal cell cultures by a magnetic bead technique (Fig. 1). The findings led the authors to demonstrate that, in mice, either B-1a or B- $1 \mathrm{~b}$ cells have a unique morphology, distinct from that of B-2 cells. The main morphological characteristic of these cells resides in bridges of the nuclear membrane, suggesting a lobular organization of the nucleus.

\section{B-1 CELLS PROLIFERATE IN VITRO}

B-1 cells represent from 10 to $15 \%$ of the total free cell population in the peritoneal cavity of mice. This paucity in cell number has been a limiting factor for the development of experiments directed to the better understanding of these peculiar cell subsets. Solving these limitations, we have developed a model to culture B-1 cells in vitro which allows the production of larger amounts of
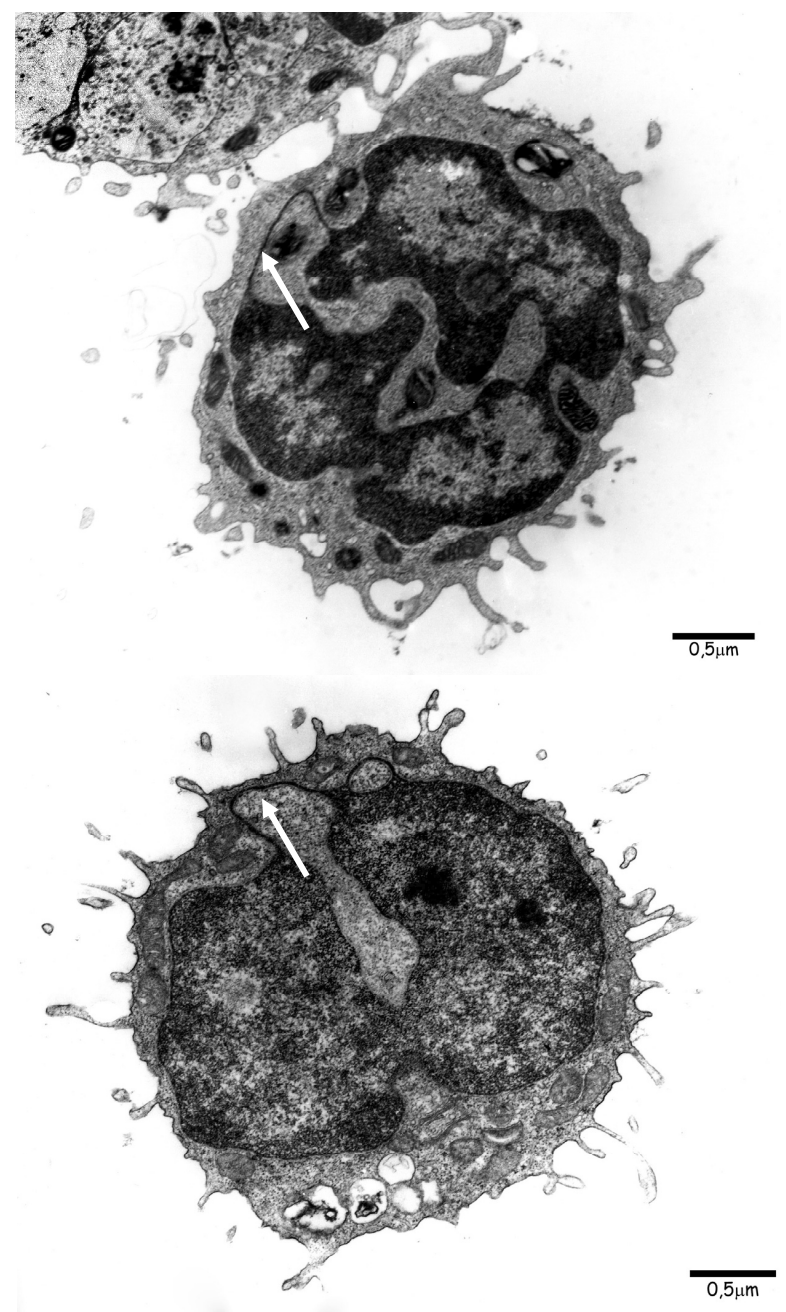

Fig. 1 - Characteristic morphology of B-1b cells. Cells were characterized as B-1 cells using colloidal gold immunocytochemical assays and purified B-1 cells from supernatants of adherent peritoneal cell cultures by a magnetic bead technique. Either B-1a or B-1b cells have a unique morphology which is distinct from that of B-2 cells. The main morphological characteristic of these cells resides in bridges (arrow) of the nuclear membrane suggesting a lobular organization of the nucleus.

them. Briefly, total mouse peritoneal cells are cultured for about $1 \mathrm{~h}$ on glass or plastic dishes. Non-adherent cells are washed out and culture medium plus $10 \%$ fetal calf serum added to the cultures which are maintained up to seven days without changing the medium. Under these conditions, B-1 cells proliferate. (Almeida et al. 2001). F.G. Thies et al. (unpublished data) have shown, in our laboratory, that B-1a cells present in the peritoneal cavity 
of mice do not have the ability to adhere to the plastic or glass surface and to differentiate into phagocytic cells.

\section{B-1 CELLS DIFFERENTIATE IN VITRO INTO A NOVEL MONONUCLEAR PHAGOCYTE DISTINCT FROM MONOCYTE DERIVED MACROPHAGES}

Borrello and Phipps (1995) have cultured B-1a cells in vitro and showed that, only when co-cultured with fibroblasts, they differentiate into a phagocytic cell similar to macrophages. Based on these observations, the authors claim that macrophages might have a distinct origin other than that from monocytes. In this direction, Almeida et al. (2001), in our laboratory, have shown that the transference of B-1b cells, obtained from cultures as above described, to a fresh culture medium induces these cells to differentiate into a bipolar mononuclear cell with a high capacity to phagocytose particles via Fc and mannose receptors. These cells were named B-1 cell derived mononuclear phagocyte (B-1DMP). Evidences that B-1DMP differentiate from B-1 cells were obtained by the demonstration that B-1 cells express both lymphoid and myeloid transcription factors. Interestingly, B-1DMP cells lose the ability to express lymphoid transcription factors and maintain the expression of myeloid factors. Further, they also lose their ability to express IgM, but maintain the rearrangement of immunoglobulin genes (Popi et al. 2009a).

Although B-1DMP can avidly phagocytose opsonized particles, Popi et al. (2009b) clearly demonstrated that these cells phagocytose higher numbers of Coxiella burneti in vitro as compared with bone marrow derived macrophages. Paradoxically, they have also shown that B-1DMP secrete large amounts of NO but kills bacteria in a lesser extent when compared with macrophages.

This phenomenon might result from contamination of the cultures with monocyte-derived macrophages as criticized by colleagues. Experimental results, however, disprove this hypothesis considering that: a) monocyte derived macrophages originate from stem cells in bone marrow of adult vertebrates. In mice, they have two waves of division to become a terminal differentiated cell, the monocyte, which may, under different types of stimulus, become a macrophage (Almeida et al. 2001). As far as we know, once differentiated into bone marrow-derived macrophages, they no longer have the abil- ity to divide. Our previous report on "macrophage" division in vitro and in vivo (Mariano and Spector 1974) was a misinterpretation of results, which will be commented later; b) if mice or total peritoneal cells are irradiated before the cells are used to culture B-1 cells as described, they do not grow, although macrophages still spread on the plastic surface. In other words, B-1cells are radio-sensitive and macrophages are well known radioresistant ones (e Brito et al. 2007); c) B-1 cells do not proliferate in culture when cells from Xid mice, an animal deprived of B-1 cells, are used and, finally, d) when anti-mouse IgM polyclonal antibody is added to the cultures plus mouse fresh serum as a source of complement, proliferation of B-1 cells is blocked, remaining only macrophages spread on the plastic surface.

One criticism for the data and for the interpretation that B-1 cells differentiate into a mononuclear phagocyte is the one of it being an in vitro phenomenon that does not occur in vivo. Evidences from our laboratory argue against these arguments considering that: a) B-1 cells migrate from the peritoneal cavity to a site of non-specific inflammation where they become morphologically similar to monocyte derived macrophages (Almeida et al. 2001); other reports in the literature confirm these observations (Borrello and Phipps 1996); b) our interpretation that foreign body giant cells resulted from the fusion of macrophages in vivo (Mariano and Spector 1974) has proved to be a mistaken interpretation since Bogsan et al. (2005), in our laboratory, have clearly demonstrated that B-1 cells are essential for giant cell formation.

These data not only demonstrate a relevant participation of B-1b cells in the kinetics of the inflammatory process, but imposes a revisit of the identification and function of mononuclear cells in inflammatory lesions. Also, the participation of B-1 cells on results obtained from experiments with "pure" cultures of adherent peritoneal cells must also be re-evaluated considering that these cells are high producers of IL-10 (Gieni et al. 1997). This issue only will be solved when specific markers for B-1 cells in tissues become available.

Taken together, these data strongly points to the existence of a B-1 cell derived from mononuclear phagocyte in adult mice distinct from monocyte-derived macrophages. If so, B-1 cells, as defined nowadays, should not be considered as a full differentiated cellu- 
lar element of the immune system but a precursor cell which, under different physiological and pathological conditions, is induced to differentiate into a mononuclear phagocyte with functions not fully understood as yet (Popi et al. 2008).

The implications of these observations in the physiopathology and immunity of B-1 cells remains open for further investigations. The "promiscuous" expression of both myeloid and lymphoid characteristics in a single cell type and the factors which govern B-1 cell differentiation in B-1DMP will certainly open new avenues for the understanding of lymphoid and myeloid cells physiopathology.

\section{B-1 CELLS MIGRATE FROM THE PERITONEAL CAVITY TO A NON-SPECIFIC INFLAMMATORY LESION}

The demonstration that B-1DMP has a high phagocytic ability the demonstration [and] that they might migrate from the peritoneal and pleural cavities to distant inflammatory lesions was mandatory. Aramaki et al. (1998) have shown that B-1 cells migrate to periodontal lesions. Almeida et al. (2001) labeled B-1 cells in culture and transferred these labeled cells to the peritoneal cavity of syngeneic naïve mice. Concomitantly, they implanted round glass coverslips into the subcutaneous tissue of the animals. Four days later, coverslips were removed and histo-autoradiograms prepared. Results showed that about $70 \%$ of the cells which adhere to the glass had their nuclei labeled, thus demonstrating that these cells have the ability to migrate from the peritoneal cavity to a distant inflammatory lesion.

These observations, added to the fact that the B1DMP cells being phagocitic, suggested that the participation of B-1DMP in inflammation should be further investigated. In this line, Bogsan et al. (2005), in our laboratory, have clearly demonstrated that B-1 cells are pivotal in foreign body inflammatory giant cell formation. Further, Vigna et al. (2006) have shown that B-1DMP cells are necessary for granuloma formation in vitro.

\section{B-1 CELLS ARE ANTIGEN PRESENTING CELLS AND ARE ENDOWED WITH REGULATORY PROPERTIES}

Vigna et al. (2006) have sown that, among other cell types, B-1 cells had the property of antigen presenta- tion. This observation suggests the possibility of these cells interacting with acquired immunity. Indeed, Alugupalli et al. (2003) have shown that B-1 cells have immunological memory. In our laboratory, De Lorenzo et al. (2007) made a very elegant experiment showing that B-1 cells have immunological memory. BALB/c mice were immunized with ovalbumin (OVA). Peritoneal cells from immunized or non-immunized mice were adoptively transferred to the peritoneal cavity of BALBc/Xid mice, characteristically deprived of B-1 cells. Later, these B-1 cells reconstituted animals which were immunized with OVA and showed that foot-pad challenge with OVA was significantly diminished in animals that received cells from previously OVA immunized animals. Also in our laboratory, De-Gennaro et al. (2009), have shown that B-1 cells participate in the mechanisms of oral tolerance. These data strongly suggest not only that B-1 cells are involved with acquired immunity but also that they might be considered as a type of Breg cell.

\section{PARTICIPATION OF B-1 CELLS IN MODELS OF INFECTIOUS DISEASE}

As B-1 cells secrete large amounts of auto-reactive IgM, it is assumed by the literature that these cells participate in the mechanisms which govern innate immunity. Nevertheless, experimental investigations question this simplistic interpretation and open the possibility that these cells might have a more complex participation in immunity. For instance, Minoprio et al. (1993) have shown that Xid mice, being animals deprived of B-1 cells, are more effective to cope with $T$. cruzi infection than with wild type controls. Moreover, Popi et al. (2008) clearly demonstrated that Xid mice, when infected intra-tracheally with $P$. brasiliensis, have a longer survival than wild type counterparts. Reconstitutions of these animals with B-1 cells turn the animals as susceptible to fungus infection as controls do. These data clearly establish a paradoxical phenomenon. Instead of participating in the mechanisms of protection against infectious agents, B-1 cells usually facilitate parasite infection. Similarly, as will be further commented, these cells also facilitate murine melanoma growth and spreading.

In accordance with this rationale, it has been recently demonstrated that $\mathrm{CBA} / \mathrm{Xid}$ mice infected with M. tuberculosis, after 20 days, bear a bacterial burden 
100 -fold smaller than that observed in wild type mice, which is assumed by the authors as a transient resistance (Junqueira-Kipnis et al. 2005). In our laboratory, a different model has been used (BALBmice Vs. BCG) and, despite not having counted CFUs as yet, if that mentioned difference is valid, it is not corresponded by a clear morphological distinction among observed lesions. Several studies showed the variable behavior of Xid mice during different infections: while resistant to T. cruzi and P. brasiliensis, they are susceptible to Borrelia hermsii (Alugupalli et al. 2003), Strongyloides stercoralis (Herbert et al. 2002), Brugia spp (Paciorkowski et al. 2000) and Schistosoma mansoni (Gaubert et al. 1999). Our results allow to state that B-1 cells have a role in the establishment of pulmonary lesions due to BCG, which favors inflammation, as clearly shown by experiments made in irradiated animals. At the $24^{\text {th }}$ day, the B-1a subpopulation seems to provide the main contribution to the infection, but both B-1a and B-1b are equally important for the establishment of inflammation after 38 days. Such cooperation between B-1a and B-1b was recently demonstrated with infections produced by Streptococcus pneumoniae (Haas et al. 2005) in which B-1a cells produce antibodies that limit infection, while B-1b cells generate a response that is sufficient to avoid death.

\section{B-1 CELLS INFLUENCE GROWTH AND SPREADING OF MURINE MELANOMA IN VIVO}

Our laboratory has generated three different lineages of murine melanoma: on the one hand, by in vivo selection and by cloning B16 mouse melanoma cells; two sublines with different behavior (high and low metastatic cells) were produced, thus creating a quantitative model for measuring metastatic capacity (Staquicini et al. 2003). On the other, starting from a non-tumorigenic melanocyte cell line (melan-a) (Bennett et al. 1987), Jasiulionis and her group, along epigenetic studies, by sequential stressing procedures of adhesion and deadhesion, were able to lead these melanocytes to malignant cell lines that, in the end, became tumorigenic and metastatic. Since the intermediary lines were also kept and available, it is now possible to investigate the development of phenotypic differences from a normal to a very malignant cell line (Oba-Shinjo et al. 2006). With these models at hand, it was possible to investigate the participation of B-1 cells in the whole process, thus reaching interesting results.

Absence of B-1 cells, as happens in Xid mice as well as in animals whose peritoneal and pleural cavities were previously irradiated, is sufficient to partially arrest B16 tumor growth and inhibit formation of metastatic pulmonary nodules. This phenomenon is not dependent on IL-10, a cytokine produced in large amounts by these cells, and can be completely reverted by the reconstitution of the B-1 population with syngeneic cells (Staquicini et al. 2008). The minor participation of IL10 in this process was confirmed by using knockout mice (Pérez et al. 2008), in which all results were very similar to those seen in wild type animals. It is dependent, however, on cell-to-cell interaction and not on soluble factors, since no differences in behavior were observed after co-cultivation with unattached cells in transwell plates. When co-cultivated, both B-1 and melanoma cells form tightly attached clusters, most probably dependent on adhesion molecules present on the surface of both cells. Also, we have shown that B-1 cells act by increasing the metastatic capacity of melanoma cells by up-regulating their amount and phosphorylation levels of the constitutionally phosphorylated extracellular signal-regulated kinase (ERK) (Pérez et al. 2008). The high malignancy of the resulting cells is probably due to differential expression of surface molecules yet to be disclosed.

The transformation of non-tumorigenic melanocyte cells into a very malignant subline by the adhesion/deadhesion procedure represents a patient and time-consuming method. Similar results, however, can be obtained by simply cocultivating melan-a in the presence of B-1 cells for 48 to 72 hs. These melanocytic cells, even after the riddance of B-1 cells, become tumorigenic and metastatic such as those coming from the sequential stress experiments. Using phage display methodology, we tried to uncover surface molecules that could have differential expression and be potentially responsible for such malignant behavior. As yet, since experiments are still ongoing, preliminary results have shown an abnormal expression of some proteoglycans, mainly Perlecan and Syndecan (A. Araujo et al., unpublished data), but further investigations are needed to assume that these are the only molecules that so drastically modify the 
metastatic phenotype of these cells. On the other hand, we have already provided enough evidence of B-1 cells influencing the out coming of murine melanoma.

\section{FINAL COMMENTS}

Little is known on the physiology of B-1 cells, as are their functions and insertion on the immune system as a whole. This is most probably due to their paucity and localization and to the difficulties of their cultivation until recently. Literature is scarce and the number of research groups dealing with these issues is very small. These circumstances made the contributions on this knowledge provided by our group already recognized by the community of investigators involved with B cells. We described how to cultivate and amplify the number of cells, showed their participation on different inflammatory processes, as well as their influence on the outcome of some tumor disorders. We also added information on migration, participation on granuloma formation and interactions with other cells, either of the immune system or from different origins. The not fully differentiated condition of these cells, which allow them, under some special situations, to perform myeloid functions, as yet confined to macrophages, must not be neglected.

Thus, our knowledge on the participation of B-1 cells in physiology and pathology has become primordial. Nevertheless, evidence that these cells are endowed with tolerogenic properties, among others, is an exciting clue to explain unsolved problems in immunopathology. One might speculate that the absence of B-1 cells in Xid mice renders these animals more resistant to infection and tumor growth due to the release of $\mathrm{T}$ cell specific functions by unknown regulatory mechanisms imposed by B-1 cells. Once definitely proved, these cells might become a population to be regarded as one of the most important lineages composing the immune system.

\section{ACKNOWLEDGMENTS}

Fundação de Amparo à Pesquisa do Estado de São Paulo (FAPESP), (Proc. 07/51501-9, 04/08506-1) for financial support.

\section{RESUMO}

A caracterização da origem, propriedades, funções e destino das células representam objetivo fundamental para a compre- ensão dos fenômenos fisiológicos e patológicos. Apesar da grande quantidade de conhecimentos relativos às diversas características das células de mamíferos, muitas delas, inclusive células B-1, são pouco entendidas. Depois de mostrar que as células B-1 podem ser cultivadas e amplificadas in vitro, uma série de experimentos visando esclarecer as propriedades dessas células puderam ser feitos em nosso laboratório nos últimos 10 anos. Assim, pudemos demonstrar que células B1 residem principalmente nas cavidades peritoneal e pleural do camundongo, migram para focos inflamatórios distantes, coalescem para formar células gigantes e participam na formação de granulomas, tanto in vitro como in vivo. São também capazes de apresentar antígenos a células responsivas e são dotadas de propriedades imuno-regulatórias. Mostramos ainda que estas células favorecem diferentes tipos de infecções bem como o crescimento e metastatização tumoral. Esses resultados sugerem que células B-1 devem exercer papel central na imunidade como um todo.

Palavras-chave: células B-1, IL-10, inflamação, infecção, neoplasia, camundongos BALB/Xid.

\section{REFERENCES}

Abrahão TB, Freymüller E, Mortara RA, Lopes JD AND MARIANO M. 2003. Morphological characterization of mouse B-1 cells. Immunobiology 208: 401-411.

Almeida SR, Aroeira LS, Frymuller E, Dias MA, Bogsan CS, Lopes JD AND MARIANo M. 2001. Mouse B-1 cell-derived mononuclear phagocyte, a novel cellular component of acute non-specific inflammatory exudate. Int Immunol 13: 1193-1201.

Alugupalli KR, Gerstein RM, CHen J, SzOMOlanyiTSUdA E, WoOdLAND RT AND LEONG JM. 2003. The resolution of relapsing fever borreliosis requires $\operatorname{IgM}$ and is concurrent with expansion of B1b lymphocytes. J Immunol 170: 3819-3827.

Aramaki M, Nagasawa T, Koseki T AND ISHIKaWA I. 1998. Presence of activated b-1 cells in chronic inflamed gingival tissue. J Clin Immunol 18: 421-429.

Bennett DC, CoOper PJ And Hart IR. 1987. A line of non-tumorigenic mouse melanocytes, syngeneic with the B16 melanoma and requiring a tumour promoter for growth. Int J Cancer 39: 414-418.

Bogsan CS, Novaes E Brito RR, Palos MDAC, MorTARA RA, AlMEIDA SR, LOPES JD AND MARIANO M. 2005. B-1 cells are pivotal for in vivo inflammatory giant cell formation. Int J Exp Pathol 86: 257-265. 
BORRELlo MA AND Phipps RP. 1995. Fibroblasts support outgrowth of splenocytes simultaneously expressing B lymphocyte and macrophage characteristics. J Immunol 155: 4155-4161.

BorRello MA AND PhIPPS RP. 1996. The B/macrophage cell: an elusive link between CD5+ B lymphocytes and macrophages. Immunol Today 17: 471-475.

CONG YZ, RABIN E AND Wortis HH. 1991. Treatment of murine CD5- B cells with anti-Ig, but not LPS, induces surface CD5: two B-cell activation pathways. Int Immunol 3: 467-476.

De-Gennaro LA, Popi AF, Almeida SR, Lopes JD AND MARIANO M. 2009. B-1 cells modulate oral tolerance in mice. Immunol Lett 2009 Apr 21. [Epub ahead of print] PMID: 19389426 [PubMed].

DE LORENZO BH, BRITO RR, GODOY LC, LOPES JD AND MARIANO M. 2007. Tolerogenic property of B-1b cells in a model of allergic reaction. Immunol Lett 114: 110-118.

E Brito RR, DE Lorenzo BH, XANder P, Godoy LC, LOPES JD, DA SILVA NP, SAMPAIO SC AND MARIANO M. 2007. Role of distinct immune components in the radiation-induced abrogation of systemic lupus erythematosus development in mice. Lupus 16: 947-954.

Förster I, Gu H, MÜller W, SChmitt M, TARLinton D AND RAJEWSKY K. 1991. CD5 B cells in the mouse. Curr Top Microbiol Immunol 173: 247-251.

Gaubert S, Viana da Costa A, Maurage CA, Lima EC, Fontaine J, Lafitte S, Minoprio P, Capron A AND GRZYCH JM. 1999. X-linked immunodeficiency affects the outcome of Schistosoma mansoni infection in the murine model. Parasite Immunol 21: 89-101.

GIENI RS, UMETSU DT AND DEKRUYFF RH. 1997. Ly1(CD5-) B cells produce interleukin (IL)-10. Cell Immunol 175: $164-170$.

Godin IE, Garcia-Porrero JA, Coutinho A, DieterLEN-LiĖVRE F AND MARCos MA. 1993. Para-aortic splanchnopleura from early mouse embryos contains B1a cell progenitors. Nature 364: 67-70.

HaAs KM, Poe JC, Steeber DA And Tedder TF. 2005. B-1a and B-1b cells exhibit distinct developmental requirements and have unique functional roles in innate and adaptive immunity to $S$. pneumoniae. Immunity 23: 7-18.

HARDY RR AND HAYAKAWA K. 1995. B-lineage differentiation stages resolved by multiparameter flow cytometry. Ann NY Acad Sci 29: 19-24.

Haughton G, ARnold LW, Whitmore AC and ClarKE SH. 1993. B-1 cells are made, not born. Immunol Today 14: 84-87.
HaYAKaWA K, HaRdy RR AND HerZENBERG LA. 1985. Progenitors for Ly-1 B cells are distinct from progenitors for other B cells. J Exp Med 161: 1554-1568.

Herbert DR, Nolan TJ, Schad GA And Abraham D. 2002. The role of B cells in immunity against larval Strongyloides stercoralis in mice. Parasite Immunol 24: 95-101.

Herzenberg LA And Kantor AB. 1993. B-cell lineages exist in the mouse. Immunol Today 14: 79-83.

Junqueira-Kipnis AP, Kipnis A, Henao TAMAYo M, Harton M, Gonzalez Juarrero M, Basaraba RJ AND ORME IM. 2005. Interleukin-10 production by lung macrophages in CBA xid mutant mice infected with $M y$ cobacterium tuberculosis. Immunology 115: 246-252.

LAlor PA, Herzenberg LA, AdAms S AND StAll AM. 1989. Feedback regulation of murine Ly-1 B cell development. Eur J Immunol 19: 507-513.

Marcos ma, Huetz F, Pereira P, Andreu Jl, MarTINEZ AC AND COUTINHo A. 1989. Further evidence for coelomic-associated B lymphocytes. Eur J Immunol 19: 2031-2035.

Mariano M AND SPECTOR WG. 1974. The formation and properties of macrophage polykaryons (inflammatory giant cells). J Pathol 113: 1-19.

Minoprio P, El Cheikh MC, Murphy E, HontebeyRie-Joskowicz M, Coffman R, Coutinho A And O'GARRA A. 1993. Xid-associated resistance to experimental Chagas' disease is IFN-gamma dependent. J Immunol 151: 4200-4208.

OBA-SHINJO SM ET AL. 2006. Melanocyte transformation associated with substrate adhesion impediment. Neoplasia 8: 231-241.

Paciorkowski N, Porte P, Shultz LD AND Rajan TV. 2000. B1 B lymphocytes play a critical role in host protection against lymphatic filarial parasites. J Exp Med 191: 731-736.

Pérez eC, Machado J Jr, Aliperti F, Freymüller E, MARIANo M AND Lopes JD. 2008. B-1 lymphocytes increase metastatic behavior of melanoma cells through the extracellular signal-regulated kinase pathway. Cancer Sci 99: 920-928.

Popi AF, Godoy LC, XANDER P, Lopes JD AND MARIANO M. 2008. B-1 cells facilitate Paracoccidioides brasiliensis infection in mice via IL-10 secretion. Microbes Infect 10: 817-824.

Popi AF, Motta Flt, Mortara RA, Schenkman S, Lopes JD And Mariano M. 2009a. Coordinated ex- 
pression of lymphoid and myeloid specific transcription factors during B-1b cell differentiation into mononuclear phagocyte in vitro. Immunology 126: 114-122.

Popi AF, ZAMboni DS, Mortara RA ANd Mariano M. 2009b. Microbicidal property of B1 cell derived mononuclear phagocyte. Immunobiology. [Epub ahead of print] PMID: 193212255 [PubMed].

Solvason N, Lehuen A and Kearney JF. 1991. An embryonic source of Ly1 but not conventional B cells. Int Immunol 3: 543-550.

Staquicini FI, Moreira CR, NASCimento FD, TerSARIOL IL, NADER HB, DIETRICH CP AND LOPES JD. 2003. Enzyme and integrin expression by high and low metastatic melanoma cell lines. Melanoma Res 13: 11-18.
StaquiCini FI ET AL. 2008. A subset of host B lymphocytes controls melanoma metastasis through a melanoma cell adhesion molecule/MUC18-dependent interaction: evidence from mice and humans. Cancer Res 68: 8419-8428.

Vigna AF, Almeida SR, Xander P, Freymüller E, MARIANO M AND LOPES JD. 2006. Granuloma formation in vitro requires B-1 cells and is modulated by Paracoccidioides brasiliensis gp43 antigen. Microbes Infect 8: 589-597. 